\title{
Bioprospecting in Colombia
}

\author{
Leonardo Güiza $^{1 \boxminus}$, Diana Bernal ${ }^{1 凹}$
}

\begin{abstract}
Despite the evolution of international policy on bioprospecting, Colombian regulations on the matter still lack uniformity with these international policies. Here we examine the effectiveness of Colombian policy on bioprospecting and its consonance with international guidelines and treaties. To this end, we requested information from the environmental authorities regarding study permits issued for scientific research on biodiversity and access granted to genetic resources. We also examined the number of research groups in Colombia registered under national directives. We found that scientific bioprospecting has increased in the last five years both in number of research groups (30\%) and in the number of registered projects $(8$ times); however, the number of undertakings does not match the number of permits issued, suggesting a margin of informality $(70 \%)$ in the execution of these activities. For the State to fulfill its duty and promote research in biodiversity, a change in policy must take place to remove the obstacles that hinder the legalization of scientific bioprospecting activities.
\end{abstract}

Keywords: Bioprospecting, biologic resources, genetic resources, research permit, public policy, biopiracy, environmental authority, Nagoya Protocol, decision 391.

Edited by Alberto Acosta

1. Grupo de Investigación en Derechos Humanos. Universidad del Rosario. Bogotá D.C.

Received: 15-04-2013 Accepted: 24-06-2013

Published on line: 16-07-2013

Citation: Güiza Leonardo, Bernal Diana (2013) Bioprospecting in Colombia. Universitas Scientiarum 18(2): 153-164 doi: 10.11144/ Javeriana.SC18-2.bc

Funding: Universidad del Rosario; Defensoría del Pueblo

Electronic supplementary material: N/A

SICI: 2027-1352(201305/08)18:2<153:BIC>2.0.TS;2-M

\section{Introduction}

Colombia has an inland area of 1'141.748 $\mathrm{km}^{2}$ and $930,000 \mathrm{~km}^{2}$ of marine area; this comprises almost $50 \%$ of the entire territory. Among megadiverse countries (14), Colombia is classified globally as a country with high biodiversity. In richness of species it is ranked in 40th place for plant diversity, 5th for mammal, 10th for bird, 30th for reptile, 20th for amphibian, freshwater fish and butterfly diversity (Andrade 2011).

Wilson, who introduced the concept of biodiversity (1985), believes that the most part, biodiversity at all levels of the biological hierarchy (CJR2008, Willies et al. 2009) remains undiscovered. The information we have is very limited. We have 
no certainty about how many species there are in the world, how many ecosystems or genetic relationships exist, or about the number of species that originate or disappear naturally or as a result of ecosystem alterations. According to a study by Moreno (2005) only 13\% of the planet's biodiversity has been identified, $0.4 \%$ of bacteria, $1 \%$ of viruses, $5 \%$ of fungi, and $23 \%$ of animals and $84 \%$ of plants.

In 1992, the Convention on Biological Diversity (CBD) was ratified by Colombia by the incorporation of Law 165, 1994 into national legislation, since then, bioprospecting has been defined as the systematic pursuit, classification and research of new sources of chemical compounds, genes, proteins and other products that make up biological diversity and which have real or potential economic value. According to Articles 3 and 15 of this Convention, access to biological resources is now considered the sovereignty of each State, and is no longer the heritage of humanity (Jeffery 2002, Duarte and Velho 2009); therefore, bioprospecting has become a strategy for developing countries, rich in biodiversity, to increase their ability to conduct scientific and technological activities. Because bioprospecting has had a research-related objective as well as a commercial purpose, a correlation between the two has been proposed grounded on basic principles aimed at the conservation of biodiversity (Castree 2003, Burtis 2007, Mishra and Tripathi 2011).

In synchrony, the Colombian Constitution established two obligations to be implemented by the State around the issue of bioprospecting: 1. The protection of diversity and the integrity of the environment (Constitution, art. 79 and 81) and 2. The expansion of research (Constitution, art. 65 and 71).

Regarding the advancement of biodiversity research, on Access to Genetic Resources and Benefit Sharing, the Nagoya Protocol (Azevedo 2005, Buck and Hamilton 2011), which was signed by Colombia in February 2011, stated in its Article 8 literal a. a that each signing State shall:

"Create conditions to promote and encourage research which contributes to the conservation and sustainable use of biological diversity, particularly in developing countries, including through simplified measures on access for non-commercial research purposes, taking into account the need to address a change of intent for such research;"

In line with Decision 391 of 1996 of the Andean Community of Nations, the Colombian State regulated scientific research on biodiversity and the access to genetic resources through Decree 309 of 2000, which was amended by Decree 302 of 2003, making a distinction between the two procedures. Accordingly, the Ministry of Environment and Sustainable Development (MADS) created special forms to request permission for scientific research in biodiversity and to access of genetic resources. Under this new regulation, Resolution 068, 2002 specifically regulates procedures concerning "study permits for scientific research in biological diversity", and Decree 309 and Resolution 620 of 1997, which have been applied in accordance with the mentioned Decree, have regulated access to genetic resources. Article 2 of Decree 309, mentions biological resources in reference to biodiversity research, it is therefore important to establish that the term "biological resource" refers to the individuals, organisms or parts thereof, populations or any biotic component of value or real or potential use in the genetic resource or its derivatives. It applies to the study of organisms, or populations excluding molecular studies. On the other hand the term "genetic resources" has been associated to all biological material containing genetic information of value or real or potential use, and it has consequently been applied in molecular studies.

It is mainly research groups that perform bioprospecting activities in Colombia. A study by Duarte and Velho (2009a) identified 71 national teams producing scientific and technological knowledge in bioprospecting. Eighty percent of these groups were from universities, 15\% from research centers and $2.8 \%$ from private companies. An analysis of 259 projects, 70\%, which included activities related to the early stages of bioprospecting such as characterization studies, isolation, identification, search, assessment and evaluation of compounds, carried out by these 71 
teams, showed that the projects had no specific application. Meanwhile, $27 \%$ of the projects carried out by these bioprospecting groups were related to a commercial application.

To carry out these projects, national researchers should adhere to the procedures set forth by Decree 309 of 2000 and Decision 391 of 1996, which include the application for a permit to carry out any scientific research project on biological diversity, and concession agreements with the State, should the project require access to genetic resources, and if necessary, undergo a consultation process. Additionally, a payment to the environmental authority service should be issued for its assessment and follow up of these permits (Resolution 260, 2011). The lack of clear guidelines on these procedures, the unfamiliarity with the rules, and the disparate interpretation of requirement and procedure instructions by both officers and researchers often make these processes expensive and time consuming (Nemogá and Diaz 2009), hindering the promotion of knowledge and the use of the country's biodiversity.

In other countries like Mexico, a portion of the State's responsibility to issue study permits has been transferred to recognized and established national researchers or their collaborators, simplifying scientific collections. Like this, a researcher holding a "scientific collector's license" can extend these permits to local and foreign, students and colleagues, although the abuse or misuse of the good faith deposited by the State on the researchers may result in criminal sanctions (Brand and Görg 2002, Soberon 2005).

In Bolivia, VMABCC Administrative Resolution No. 026 of 2009 has established that only Authorized Scientific Institutions (ICA) may submit research projects for approval to the National Competent Environmental Authority $(\mathrm{AACN})$. In this sense, institutions developing, presenting, performing or following scientific research projects must first be registered with the AACN. In Ecuador, under the Unified Text of Secondary Environmental Legislation of the Ministry of Environment, scientific research in biodiversity within national Natural Heritage
Areas requires the authorization of the applicable Regional District, and investigations outside the national Natural Heritage Areas do not require research authorizations, unless the project involves the collection of specimens or samples. Lastly, Peru has detached scientific research within protected areas from research conducted outside of them. In the first case, the National Service of State Protected Natural Areas is responsible for issuing permits, and in the second case, the General Forestry and Wildlife Office is the responsible agent.

Each country's position on implementing restrictive or permissive regulations to authorize bioprospecting practices depends largely on which type of policy better prevents biopiracy, that is, the inequitable distribution of benefits, or the use and appropriation of these biological or genetic resources outside of the framework of the law (Hamilton 2006, Gómez Lee 2008, Ragavan 2008, Birhanu 2010, Saccaro 2011).

Often countries with higher rates of biodiversity opt for restrictive legislation on bioprospecting practices due to concerns fostered by what some writers have called bioimperialism (Duarte and Velho 2009b). Conversely, some countries have seen in their natural wealth and in the interest of developed countries an advantage to strengthen their scientific and technological capabilities, the understanding of their biodiversity and the ability to maximize the allocation of benefits.

Thereon, Colombian government implemented Conpes document 3582 of 2009, which promoted a national policy on biodiversity research, and established conditions to convert the understanding of natural wealth into a national growth and development strategy (Conpes 2009). Similarly, Conpes document 3697 of 2011, which generated the policies on biocommerce and biotechnology, has sought to "promote value chains for naturalingredients used in cosmetics and pharmaceuticals, and natural ingredients for the food industry, as well as for flowers and tropical foliage, Amazon fruit trees, crafts and ecotourism" (Conpes Document 2011); this requires scientific research on biological resources and activities to access their genetic resources. Recently, MADS 
issued the National Comprehensive Management of Biodiversity and Ecosystem Services Policy. This policy recognized the involvement of diverse actors, whose interaction can simultaneously strengthen the participation in the system and also generate a series of socio-environmental conflicts generated by tensions, disagreements, confrontations and clashes between them (MADS 2011).

The legislation applied to these procedures, established a series of steps entailing strict compliance. The elicitation procedure for a biodiversity research study permit has a duration of 30 days and requires the following steps: a) submittal of the completed application form to the competent environmental authority, b) assessment by the environmental authority of the documents and information submitted c) additional requirements, if necessary; d) issuance of an administrative act by which the permit is granted or denied, if granted, e) publication the abridged permit in a newspaper of national circulation. According to the provisions of Art. 4 of Decree 309 of 2000, the environmental authorities responsible for issuing study permits for scientific research are: a) Regional Autonomous or Sustainable Development Corporations or the Environmental Authorities of major urban centers where research activities take place exclusively in their respective jurisdictions, and b) the Ministry of Environment when research takes place in Colombian marine areas. Permits for research activities within the National Parks system are issued by the Special Administrative Unit of the National Parks System (MADS 2006)

Meanwhile, there are 10 steps which must be followed to attain a permit to access genetic resources: a) submittal of the completed access to genetic resources application form to the National Environmental Licensing Authority (ANLA), b) assessment by the agency of the legal documents required c) request for additional information, d) issuance of the procedure start authorization, e) drafting of a technical concept by the Agency, f) holding of the prior consultation, if necessary, $g$ ) development of legal expert opinion, h) issuing the administrative act that accepts or denies the application, i) access to genetic resources contract negotiation, and j) signing of access to genetic resources contract. According to regulations, this procedure takes from 30 to 45 days and is processed by the ANLA in accordance with the provisions of Decision 391 (MADS 2006a).

However, analyses of the effectiveness of the Colombian legal system in this area indicate that despite establishing an explicit set of regulations, the implementation of Decision 391 in Colombia has generated negative impacts in the field of scientific research (Nemogá and Díaz 2009, Duarte and Velho 2009). It has hindered the development of the country's biodiversity research activities and has fostered the current state of illiteracy on biodiversity.

Befittingly, in August 2012 the Andean Community of Nations reactivated the Andean Committee on Genetic Resources to review Decision 391, especially in light of the Nagoya Protocol, scientific and technological advancements and the state of international regulations. Colombian government, in turn, began an evaluation of Decree 309 of 2000; its revision was presented to the scientific and academic community in early 2013 , prior to its final implementation. This revised proposal sought especially to regulate the access to genetic resources from scientific biodiversity collection permits issued for non-commercial scientific research.

In this context, the objective is to illustrate the effectiveness of policies and rules governing bioprospecting activities for scientific purposes in Colombia. To do this, we first examined the operability of biological resources research permits. Then, we analyzed the effectiveness of bioprospecting or access to genetic resources authorization procedures. The third approach was to identify and analyze the evolution and challenges of research groups carrying out these activities, and lastly, we identified the sanctions imposed to those carrying out bioprospecting activities without due consent.

\section{Materials and Methods}

This article is the product of research supported by the Colombian Office of the Ombudsman, through whom we obtained information from 
the Colombian environmental authorities, namely, the Autonomous Regional Corporations and the Colombian National Natural Park System, as well as information from records by the Ministry of Environment and Sustainable Development's Public Registry of Access to Genetic Resources, (MADS) as part of our research on Access to Genetic Resources. Supporting data is derived from the following sources:

\section{a) To document study permits for research in} biological diversity: 1. A report on biodiversity research permits issued nationwide, requested by the Ombudsman from the Autonomous Regional Corporations and the National Park System. The report assembled information on 336 biological resource research permit applications from January 2008 to March 2013. The following variables were analyzed from this information: start and termination date, administrative acts, research location, nature of the applicant (university, research center, private entity) purpose of the project, species to be studied, and whether the authorization was conditioned by the access to genetic resources.

b) To document access to genetic resources authorizations: 2. Review of the MADS public record of access to genetic resources (hereinafter public record) that collected information from 107 applications submitted from January 2008 to March 2013. The following variables were taken into account: project name, applicant, start authorization and approval. This record is posted on the organization's website. Given that the record is updated to 2012, we completed it by using administrative acts granting authorizations for access to genetic resources during the first quarter of 2013, giving us a total of ten.

3. A review of 57 access to genetic resources permits $(100 \%)$ emitted from January 2008 to March 2013 by MADS and ANLA, to analyze five variables: time between the application and the final decision by the Authority; limitations or restrictions on the use of genetic material; if it took place, cause of request denial; if it was the case, time between scientific research permit and the decision regarding access to genetic resources; and, specific activities outlined for access to the genetic resource. These administrative acts were collected by request of the Ombudsman to MADS and ANLA and through consultations to the Environmental Gazette, available on these organization's websites.

\section{c) Todocument bioprospectingresearch in Colombia:} 4. A review of all the bioprospecting projects registered on the Science and Technology (Scien'Ti) platform, which collects information from all the Colombian research groups (GrupLAC) registered with Colciencias. Once the groups participating in bioprospecting projects (105) were identified, we analyzed three variables: the nature of the institution conducting the research (university, research center or private entity), the number of bioprospecting research projects and whether the bioprospecting activity was for commercial or scientific purposes. We entered keywords "bioprospecting", "biodiversity", "prospecting of biodiversity", "biocommerce", "bioactivity", "phytochemical", "natural products" and "genetic resources" into the GrupLAC module of this platform. The fields: group name, lines of research, projects completed or in progress and products of different research groups, were used to perform the search. The data taken into account included research from January 2008 to March 2013.

\section{d) To determine administrative sanctions imposed for non-compliance with bioprospecting} regulations: 5. A review of administrative sanctions imposed by environmental authorities from January 2008 to March 2013 as a result of bioprospecting activities that did not comply with the requirements established for that purpose. This record of sanctions was requested through the Ombudsman and referred to using the Environmental Gazette available on the MADS and ANLA website.

The information obtained on the number of access to genetic resources and biodiversity research permits issued per year, permits issued by environmental authority, research permits and permit processing times was used to create the frequency diagrams in Figure 1. 

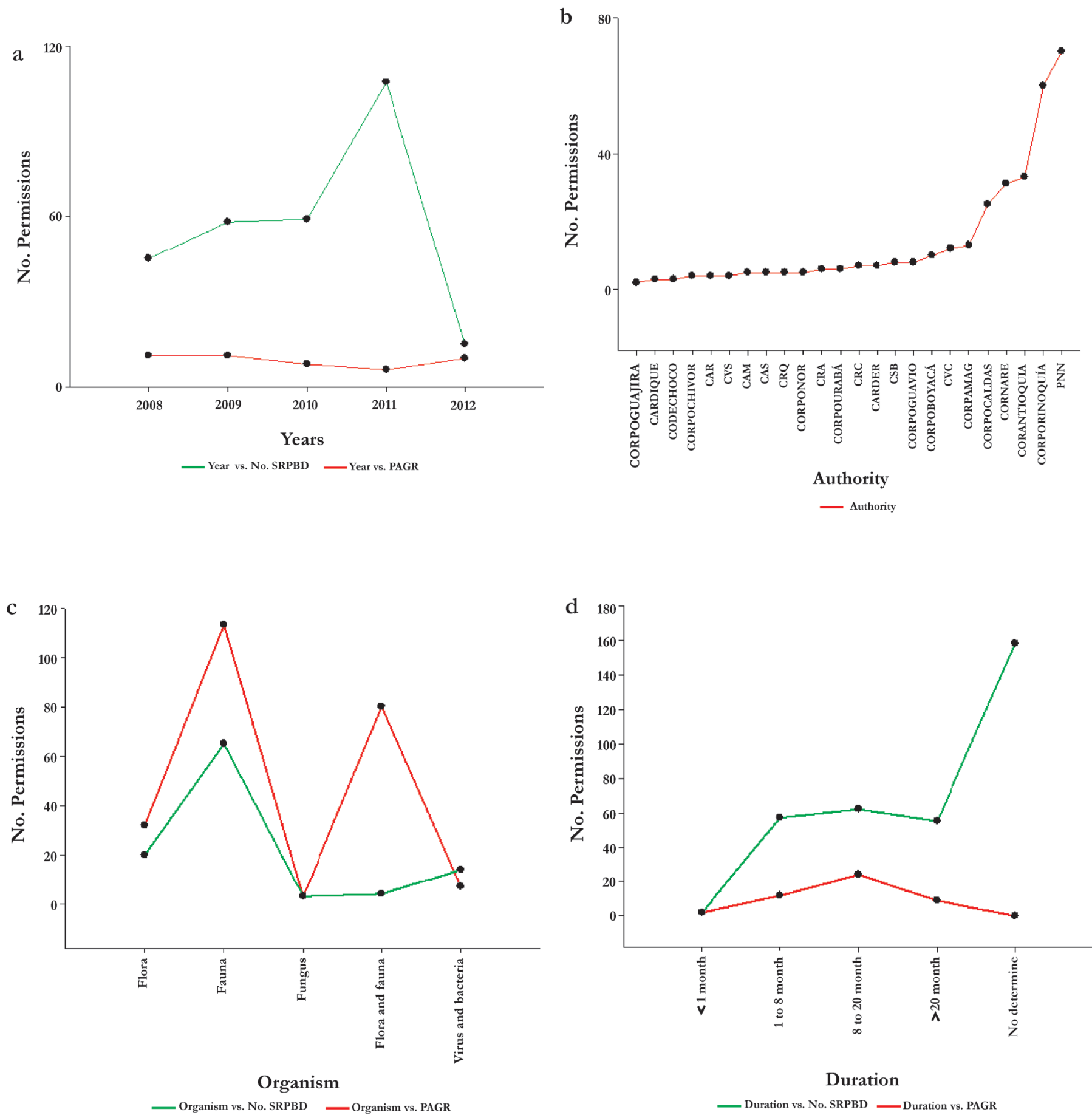

Fig. 1. Permits data for access to genetic resources and scientific research on biological diversity in Colombia 2008-2013. a. Scientific research permits issued for biological diversity studies and Access to Genetic Resources permits issued between 2008-2013. b. Study permits for scientific research in biological diversity issued by the Regional Environmental Authorities and National Parks System (PNN). c. Division of organisms being studied under biodiversity scientific research permits and access to genetic resources permits $\mathbf{d}$. Scientific research for biodiversity study permits and access to genetic resources application processing times 


\section{Results}

Study permits for scientific research in biological diversity: According to the information provided by 24 of the 28 Colombian Environmental Authorities (Regional Autonomous Corporations in Colombia established as environmental authorities able to issue permits for research on biological resources and the National Parks System of Colombia-SPNN) 336 study permits were granted during January 2008 to March 2013, the highest number (32\%) was granted in 2011 and the lowest (4\%) in 2012 (Figure 1a).

According to study permit reports, National Parks of Colombia was the environmental authority that granted the highest number of permits during the period studied (21\%), followed by Corporinoquía $(18 \%)$. It is worth noting that Corpoguajira, Cardique Codechocó and have each issued less than $1 \%$ of these permits. Similarly, $5 \%$ of the permits were conditioned to the request for access to genetic resources, therefore, $95 \%$ is related exclusively to biodiversity research permits (Figure 1b).

While the largest percentage of research permits was issued by the Colombian National Parks System, this system consists of 56 areas, and research permits were processed for only 26 areas, implying that in $54 \%$ of these areas biodiversity has not been researched or at least no study permits were issued for research in these areas.

Most of the study permits found were related to research on fauna $(34 \%)$ and flora $(10 \%)$ and were related with undergraduate and graduate thesis projects in which the understanding of biodiversity, and in the case of flora, the properties of plants and their applications, predominated. In $30 \%$ of the cases, the species relevant to the study for which the permit was granted was undetermined (Figure 1c).

A large percentage $(87 \%)$ of the applications submitted were for academic purposes, while 13\% of them were for environmental impact studies intended for future hydrocarbon exploitation license applications. Applicants for these permits were, in their majority, natural persons with no institutional filiation declared (214), followed by universities (45), then private entities (44), and centers for research (29), four applications made no specification as to the permit holder. All of the private entities applying for these permits did so in the context of environmental impact studies for future project development.

As stated in Article 9 of Decree 309 of 2000, the environmental authority must grant or deny the permit within thirty days from submittal of the application. However, this was only the case in $4 \%$ of the requests. Thirty-two percent of these requests take between 1 and 8 months to be processed, 34\% between 8 and 20 months and $30 \%$ between 20 and 60 months (Figure 1d).

Bioprospecting or access to genetic resources authorizations: According to the MADS public register of access to genetic resources, there have been 107 applications submitted between 2008 to March 2013 (Figure 1a). The highest percentage of requests was for access to fauna $(61 \%)$ and flora $(19 \%)$ genetic resources (Figure 1c).

Of the 107 applications for access to genetic resources, $44 \%$ obtained the corresponding access to genetic resources contract, while $27 \%$ despite having had authorized access to genetic resources, did not make it past the negotiation stage, which is concretized in the respective contract. Equally, $14 \%$ of the requests did not obtain a document to start the administrative process and $15 \%$ of the applications were filed during the processing of the permit. A total of 47 permits to access genetic resources were implemented, that is, only $27 \%$ of applications were accepted.

According to the information obtained from public records, and supplemented by administrative acts carried out by ANLA and MADS between January 2008 and March 2013, authorizing or denying access to genetic resources, the duration of the procedure has been between 1 and 65 months. Only 2\% were approved within 30 days. Twenty-three percent were authorized between 1 and 8 months, $32 \%$ between 8 and 20 months and $43 \%$ between 20 and 65 months (Figure 1d). 
It is worth noting that of all the administrative acts authorizing access to genetic resources made from January 2008 to March 2013 by ANLA and MADS, only $21 \%$ mentioned any of the limitations on the access to genetic resources or their derivatives specified in any of the sections of Article 45 of Decision 391 of 1996, whether partial or total. The limitations most often mentioned were the vulnerability or fragility of the ecosystems' structure or function that could be aggravated by access activities $(70 \%)$, followed by the adverse effects of access activities on human health or on cultural identity $(20 \%)$, and species, subspecies, variety or race, endemism, rarity or endangered state $(10 \%)$.

During this period, only one application was denied based on perceived methodological inconsistencies regarding the samples, the validity of the subcontract, sampling protocols used during shipping and capture and sacrifice, along with the contingency plan for the rescue of arboreal animals that remain at risk following sedation.

In $2 \%$ of the cases, less than 30 days transpired between the issuance of the scientific research permit and the decision regarding access to genetic resources, between 1 and 4 months in 9\% of cases, 4 to 8 months in $23 \%$ of cases, 8 to 20 months in $18 \%$ of cases and 20 to 79 months in $20 \%$ of cases. Note that in $16 \%$ of cases, the environmental authority issued one administrative act authorizing biological resources research and the access to genetic resources. And lastly, in 9\% of cases, applications forwent a permit to perform biological resources research and requested only permission to access genetic resources.

Bioprospecting research groups: Of the research groups registered with Colciencias, we found 105 groups that registered bioprospecting projects between January 2008 and March 2013. Ninety-one are ascribed to universities, 11 to research centers and 3 to private entities.

The total number of bioprospecting projects registered by these groups is 1904, of which, 1676 $(88 \%)$ are non-commercial and are purely projects conducting academic activities, while 228 (12\%) are commercial projects.
Sanctions imposed for unauthorized bioprospecting activities: In accordance with Article 46 of Decision 391, and Act 1333 of 2009 which established the proceedings of environmental sanctions, persons carrying out bioprospecting activities without due authorization shall be punished; however, only one sanction has ever been imposed in Colombia on this account. Under MADS Resolution 1459 of July 29, 2010 the Institute of Biotechnology IBUN of the Universidad Nacional de Colombia, was sanctioned for violating environmental regulations set forth in Article 16 of Andean Decision 391 of 1996 and accessing genetic resources by isolating and identifying a microorganism belonging to the genus Lactococcus sp, and obtaining, for research purposes, a naturally occurring biopolymer created by the microorganisms enzymatic activity without having registered the pertinent access contract with the State through MADS. They were fined an amount nearing USD \$7,000.

\section{Discussion}

Study permits for scientific research in biological diversity: As mentioned, there has been no research on biodiversity in more than half of the nation's natural protected areas, or at least, there were no such permits registered. This implies that while these areas are rich in biodiversity, a policy to promote research activities to identify the biodiversity of these protected areas has not been implemented; this would involve human, technological, and economic resources.

It is important to highlight that while fauna and flora in Colombia are the realms most often studied as biological (68\%) and genetic (83\%) resources, much remains unexplored in the study of bacteria, viruses and fungi, as they are globally the least studied kingdoms (Moreno 2005).

It is thought provoking that regarding environmental licensing, only projects involving hydrocarbons requested permits for biological resourcesresearch. According to regulations current during the period of this research (2008-2013) all types of projects requiring an environmental permit also require an environmental impact 
study, most of which in turn, require biodiversity studies.

Bioprospecting or access to genetic resources authorizations: If we consider that between January 2008 and March 2013, 105 research groups registered 1,904 bioprospecting projects with Colciencias and that during this time 336 biodiversity research permits and 57 access to genetic resources authorizations were issued, we can assume that roughly $77 \%$ of the projects conducted in the country are being done without due authorization.

On the other hand, the percentage of successful access to genetic resources applications (27\%) during the study period is very low. This is highly discouraging to scientific research in the country and contravenes the State's duty, established in Decision 391 and the Nagoya Protocol, to promote biodiversity awareness in Colombia.

Another major obstacle faced by researchers is the inordinate amount of time required by environmental authorities to adjudicate on biological resources research permits and access to genetic resources. Sixty-four percent of study permit applications and $75 \%$ of access requests took more than 8 months to be determined (Figure 1d); this is detrimental to research undertakings as it stalls their evolvement until they can obtain the appropriate permissions.

Bioprospecting research teams: Based on the figures reported by Duarte and Velho (2009a), the number of bioprospecting research groups rose from 71 to 105, an increase of $30 \%$ in five years from January 2008 to March 2013. Similarly, primary bioprospecting activities increased by $10 \%$ from 2008 to 2013, and commercial prospecting decreased in the same proportion; this suggests that regulation discourages this type of prospecting for industrial applications. In the last five years, the overall number of bioprospecting undertakings in Colombia increased nearly 8 times suggesting the importance this subject is acquiring within the country's scientific interests.

The study on the effectiveness of the Colombian system on this matter evinced that although the implementation of CAN Decision 391 has enabled the creation of legislation particular to this topic, it has also generated negative impacts for scientific research, to the extent that illicit prospecting activities have become common. In an effort to prevent this clandestinity, Decree-Law 19 of 2012 extended a one-year amnesty to researchers prospecting without the permits necessary to legalize their access to genetic resources activities. However, this legislative initiative failed in practice; according to the information provided by MADS, no new genetic resource access contracts were reported during the term of this amnesty. Some of the issues potentially causing these high levels of clandestinity in bioprospecting for scientific purposes are:

1) Delays in issuing biological resources study and access to genetic resources permits: as corroborated by Gomez and Nemogá (2007), lead times are not met. While it is fitting to differentiate between the two processes, the procedures to fulfill the first process are just as dilatory as the second. Consequently, an excessively restrictive legislation does not guarantee, in the case of research or access to genetic resources for commercial purposes, a better position in negotiation. The evidence points to a policy that better balances access and distribution, that will afford supplying countries, such as Colombia, a better use of their resources while respecting established conservation and sustainable use policies (Hervé 2007).

2) Unfamiliarity with applicable regulations: The lack of clarity and unawareness of the scope of the regulations creates inconsistency in the processes. When information reported by the CAR is contrasted with publications or information on the Colciencias platform, we found that projects were commenced or their results had already been prior to being issued a permit by the environmental authority; hence, the permissions were requested in order to legalize research projects in which, for example, the collection of specimens had already taken place.

3) Unclear applicability of rules to the proceedings: In some cases, in permissions were granted to research natural resources, despite the 
applicable regulations stipulated in Decree 309, only to later be revoked on the grounds of breach of obligations in accordance with this Decree.

4) Institutional Ineffectuality: A substantial lack of knowledge and expertise as well as a deficiency in technical and administrative skills was blatant in the representatives functioning in the offices of the environmental authorities of the country. Despite the existing conversation on the prevalent illegality of research biodiversity in the country, the sanctions and limitations provided by law are not enforced. Forasmuch, it is crucial that we strengthen, as it is in most developing countries that are rich in biodiversity, the competencies and the institutional infrastructure required to meet the challenges in these areas (Chandra and Idrisova 2011). Added to this, are the glaring shortcomings of the information system that manages the applications and the permits for both biological resources research and access to genetic resources. In addition to missing information, the existing information was outdated; this impeded a comprehensive gauging of the country's awareness of its biodiversity.

5) Failure to coordinate between entities: There is no coordination between environmental authorities and the National Department of Science and Technology, the entity responsible for implementing research promoting policies, regarding the enforcement and the requirements of research permits. To illustrate, one of the requirements set forth by Colciencias to finance research projects related to biological resources or access to genetic resources, was to apply and obtain the appropriate permit from the competent environmental authority. As a result, the small financial investment allocated by the State to promote understanding of the country's biodiversity was squandered due to existing legal and administrative impediments.

The new regulations proposed by Decree 309 of 2000, which regulates the issue of bioprospecting of biological resources and genetic resources permits, do not set apart commercial intended research and research conducted for strictly academic purposes. While the proposed amendments to Decree 309 establish the possibility of framework agreements for scientific research, there was no clarity on the benefits they would afford the institutions. The differentiation between the provisions relating to commercial studies, and those regarding academic research, is ambiguous. In some cases, the procedures failed to expedite the prior but did manage to make the permit application process more complex for the latter. There is still no clear policy to promote research and promote knowledge regarding the country's biodiversity.

Sanctions for unauthorized bioprospecting activities: There were few sanctions imposed for the unauthorized execution of these activities, akin to the high degree of informality of scientific bioprospecting in Colombia; this largely due to state management, and unclear procedures and lengthy and inefficient formalities.

\section{Conclusion}

We estimate that the informality of bioprospecting in the country exceeds $70 \%$. Given the current regulatory framework in the field of bioprospecting in Colombia, researchers conducting scientific bioprospecting activities in the country encounter several obstacles to achieve the legalization of these undertakings. The main obstacle is the wait time required for competent authorities to reach a decision regarding the request. Deadlines were met in less than $4 \%$ of cases and in three quarters of cases, environmental authorities took more than 20 times the period stipulated for these proceedings. These delays are compounded by the tremendous increase in the number of research groups $(30 \%)$ and bioprospecting related research projects (8 times) in the last five years.

In concomitance with the data obtained and its analysis, and as Melgarejo (2013) duly noted, the policies and regulations issued by the Colombian State must foster greater access to knowledge and augment the understanding of biodiversity. It must overcome the deficiencies in infrastructure, and improve the consistency in regulation, as well as develop the interaction between industry, State and academia. The proposed procedures should be modified to counteract these deficiencies and they 
must, especially, it must include all the different actors involved in bioprospecting activities. Lastly, the State must take into account the discussions within the CAN work group on genetic resources.

\section{Acknowledgments}

This work was funded by the Universidad del Rosario and Defensoria del Pueblo.

\section{Conflicts of interests}

The authors declare no conflicts of interest.

\section{References}

Alho CRJ(2008) The value of biodiversity. Brazilian Journal of Biology 68(4s):1115-1118.

Andrade G (2011) Estado del conocimiento de la biodiversidad en Colombia y sus amenazas. Consideraciones para fortalecer la interacción ciencia-política. Revista de la Academia Colombiana de Ciencias Exactas, Físicas y Naturales 137(35):491-507

Azevedo CMA (2005) Regulation to access to genetic resources and Associated traditional knowledge in Brazil. Biota Neotropica 5(1):19-27

Birhanu F M (2010) Challenges and prospects of implementing the access and benefit sharing regime of the Convention on Biological Diversity in Africa: the case of Ethiopia. International Environmental Agreements: Politics, Law and Economics 10(3):249-266

Brand U, Görg C (2003) The state and the regulation of biodiversity International biopolitics and the case of Mexico. Geoforum 34(2):221-233

Buck M, Hamilton C (2011) The Nagoya Protocol on Access to Genetic Resources and the Fair and Equitable Sharing of Benefits Arising from their Utilization to the Convention on Biological Diversity. Review of European Community \& International Environmental Law 20(1):47-61

Burtis P (2007) Can Bioprospecting Save Itself? At the Vanguard of Bioprospecting's Second Wave. Journal of Sustainable Forestry 25(3-4):218-245

Castree N (2003) Bioprospecting: from theory to practice (and back again). Transactions of the Institute of British Geographers 28 (1): 35-55

Chandra A, Idrisova A (2011) Convention on Biological Diversity: a review of national challenges and opportunities for implementation. Biodiversity and Conservation 20(14): 3295-3316
Consejo Nacional de Política Económica y Social (2009) Documento Conpes 3582. Política nacional de ciencia, tecnología e innovación. República de Colombia, Departamento Nacional de Planeación, Bogotá

Consejo Nacional de Política Económica y Social (2011) Documento Conpes 3697. Política para el desarrollo comercial de la biotecnología a partir del uso sostenible de la biodiversidad. República de Colombia, Departamento Nacional de Planeación, Bogotá

Duarte O, Velho L (2009a) Capacidades científicas y tecnológicas de Colombia para adelantar prácticas de bioprospección. Revista Iberoamericana de Ciencia Tecnologia y Sociedad 4(12):55-68

Duarte O, Velho L (2009b) La bioprospección como un mecanismo de cooperación internacional para fortalecimiento de capacidades en ciencia y tecnología en Colombia. Ciência da Informação 38(3):96-110

Gómez D, Nemogá G (2007) Ilegalidad de la investigación genética en Colombia. Pensamiento Jurídico 18:265-284

Gómez Lee MI (2008) El TLC es inconstitucional por legitimar la biopirateria en contra del interés nacional. Revista Oasis 13:115-143

Hamilton C (2006) Biodiversity, biopiracy and benefits: what allegations of biopiracy tell us about intellectual property. Developing Bioethics 6(3):158-173

Hervé E (2007) Hacia el establecimiento de una fórmula normativa sustentable para incentivar la utilización de los recursos genéticos. Revista de Derecho 20(1):123-148

Jeffery M (2002) Bioprospecting: Access to Genetic ResourcesandBenefit-Sharingunder the Convention on Biodiversity and the Bonn Guidelines. Singapore Journal of International \& Comparative Law 6(2):747808

Melgarejo LM (2013) Bioprospecting as a possible development mechanism for Colombia. Acta biológica Colombiana 18(1): 19 - 30

Ministerio de Ambiente y Desarrollo Sostenible (2011) Política Nacional de Gestión Integral de la Biodiversidad y sus Servicios Ecosistémicos. www. minambiente.gov.co. Consultado Noviembre 21 2012

Ministerio de Ambiente y Desarrollo Sostenible (2006). Contrato de Acceso a Recursos Genéticos. www. minambiente.gov.co. Consultado Marzo 102012

Ministerio del Medio Ambiente y Desarrollo Sostenible (2006a). Permiso de Estudio con Fines de Investigación Científica en Diversidad Biológica. www.minambiente. gov.co. Consultado Marzo 102012 
Mishra N, Tripathi P (2011) Biodiversity information managment-legal aspects. Science Reporter 48(2):31-34

Moreno M (2005) Avances en el conocimiento de la Biodiversidad: Especies. Boletín de la Real Sociedad Española de Historia Natural, Sección Biológica 100(14):19-30

Nemoga G, Rojas D (2009) Algunas lecciones sobre el acceso a recursos genéticos en Colombia. Dos estudios de caso. Acta Biológica Colombiana 14(2):137-160

Organización de las Naciones Unidas (1992) Convenio de Diversidad Biológica (texto con anexos). ONU, New York

Ragavan S (2008) New Paradigms for Protection of Biodiversity. Journal of Intellectual Property Rights 13(5):514-522

\section{Bioprospección en Colombia}

Resumen. A pesar del avance en el marco regulador internacional sobre bioprospección, la normatividad interna carece de uniformidad en torno a la política internacional en la materia. Por tal razón, se analizó la eficacia de la política colombiana sobre bioprospección en consonancia con las directrices y tratados internacionales, para evidenciar su nivel de cumplimiento. Se solicitó información a las autoridades ambientales sobre los permisos de estudio con fines de investigación científica en diversidad biológica y acceso a recursos genéticos y se consultó el registro de los grupos de investigación en Colombia a la luz de la regulación nacional. Se evidenció que la actividad científica en bioprospección ha crecido en los últimos cinco años tanto en número de grupos de investigación (30\%) como en número de proyectos registrados (ocho veces). Sin embargo, el número de proyectos no coincide con el número de permisos, verificándose un margen de informalidad (70\%). Los obstáculos para la legalización de las actividades científicas en biodiversidad hace necesario cambiar las normas para que el Estado cumpla con su deber de promoción de la investigación en el tema.

Palabras clave: Bioprospección, recursos biológicos, recursos genéticos, permiso de investigación, política pública, biopiratería, autoridad ambiental, Protocolo de Nagoya, Decisión 391.
Saccaro Jr (2011) A regulamentação de acesso a recursos genéticos e repartição de benefícios: disputas dentro e fora do Brasil. Ambiente \& Sociedade 14(1):229244

Soberón J (2005) Comentarios sobre la legislación de México en relación con el acceso a los recursos genéticos. Biota Neotropica 5(1):29-32

Wilson E (1985) Time to revive systematics. Science 230(4731):1227

Willis K J, Bennett K D, Bhagwat S A, Birks HJ (2010): $4{ }^{\circ} \mathrm{C}$ and beyond: what did this mean for biodiversity in the past? Systematics and Biodiversity 8(1): 3-9

\section{Bioprospeção em Colômbia}

Resumo. Apesar da evolução das políticas internacionais em bioprospeção, os regulamentos Colombianos carecem de uniformização com estas políticas. Examinámos a eficácia das políticas Colombianas em bioprospeção e sua concordância com normas e tratados internacionais. Para este fim, solicitamos informação das autoridades ambientais sobre licenças de emissão de estudo para a investigação científica sobre biodiversidade e acesso concedido a recursos genéticos. Ademais, examinamos o número de grupos de investigação em Colômbia registados sob diretrizes nacionais. Descobrimos que a bioprospeção científica tem aumentado nos últimos cinco anos, tanto em número de grupos de investigação $(30 \%)$ como no número de projetos inscritos (8 vezes), porém o número de projetos não coincide com o número de licenças emitidas, sugerindo uma margem de informalidade $(70 \%)$ na execução dessas atividades. Para o Estado cumprir o seu dever e promover a investigação em biodiversidade, uma mudança na política deve ser feita para remover os obstáculos que impedem a legalização das atividades científicas de bioprospeção.

Palavras-Chave: Bioprospeção, recursos genéticos, autorização de investigação, políticas públicas, biopirataria, autoridade ambiental, Protocolo de Nagoya, Decisão 391 